\title{
GLOBAALIN KOULUTUKSEN TILAN JA TULEVAISUUDEN POHDINTAA
}

\section{Huippuasiantuntijat kohtasivat: kuulumisia Turun yliopistossa järjestetystä kansainvälisestä symposiumista 1.-2.10.2004}

Lokakuun alun kaksi aurinkoista päivää olivat kuin kirkas välähdys muuten niin harmaassa arjessa. Kauniin syysaamun koitteessa Turun yliopiston kasvatustieteiden laitokselle kerääntyi joukko kansainvälisiä ja kotimaisia koulutusalan huippuasiantuntijoita. Supranational Regimes and National Education Policies - Encountering Challenge-symposium 1.-2.10.2004 alkoi varhain perjantaiaamuna viimeistä paikkaa myöten täydessä luentosalissa ja päättyi vilkkaaseen paneelikeskusteluun lauantai-illansuussa. Symposiumia seuraamaan oli saapunut vertailevan kasvatustieteen kotimaisia ja kansainvälisiä tutkijoita, OECD:n ja suomalaisen opetushallinnon edustajia, virkamiehiä, yliopistoväkeä ja opiskelijoita. Turun yliopiston Elinikäisen oppimisen ja koulutuksen tutkimuskeskuksen (CELE) ja Kasvatusalan valtakunnallisen tutkijakoulun KASVA:n jär- 
jestämä tilaisuus oli alallaan kotimaisessa mittakaavassa ainutlaatuinen. Järjestäjät olivat saaneet paikalle peräti 17 teemaan hyvin valittua puhujaa ja panelistia, joista puolet oli ulkomailta. Kansainvälisen koulutustutkimuksen huippuasiantuntijoista mukana oli useita tunnettuja nimiä kuten OECD:n koulutuspolitiikan historian Grand Old Man George Papadopoulos sekä professorit Roger Dale, Andy Green ja Susan Robertson. Suomesta symposiumissa alustivat mm. korkeakouluneuvos Anita Lehikoinen, opetusneuvos Reijo Laukkanen, professori Markus Jäntti sekä paneelissa kansleri Christoffer Taxell. Tilaisuus liittyi keskeisesti Suomen Akatemian tukemaan tutkimushankkeeseen OECD Education Policies: Three National Cases, jonka tiimoilta symposiumissa kuultiin kolme alustusta (Rinne, Kallo ja Hokka).

Symposiumin tavoitteena oli muodostaa laaja-alainen ja tieteiden rajat ylittävä kuva globalisaatiosta, ylikansallisesta koulutuspolitiikasta ja kansallisen koulutuksen tulevaisuudesta. Huomio kohdistettiin erityisesti OECD:n, Euroopan unionin ja Maailman kauppajärjestön (WTO, World Trade Organisation) politiikkoihin ja niiden vaikutuksiin kansallisessa koulutuspolitiikassa.

\section{AVOIMEN KOORDINOINNIN MENETELMÄ MALLIKSI?}

Y ksi keskeisistä symposiumissa esillenousseista teemoista oli ns. avoimen koordinoinnin menetelmä (OCM, Open method of coordination) ja sen merkitys kansallisessa koulutuspolitiikassa. Menetelmää voidaan luonnehtia poliittiseksi hallintamuodoksi, joka perustuu Euroopan unionin jäsenmaiden väliseen yhteistyöhön ja tiedonvaihtoon sekä maakohtaisen edistymisen mittaamiseen sovituilla välineillä. Tätä kautta tarkoituksena on löytää parhaat toimintatavat (best practices) ja levittää ne unionin eri jäsenmaihin. Menetelmän avulla tähdätään Lissabonin huippukokouksessa esitettyyn päämäärään rakentaa Euroopan unionista maailman kilpailukykyisin ja dynaamisin tietoon perustuva talous.

Avoimen koordinoinnin menetelmää sovellettiin aluksi edistämään eurooppalaista työmarkkinapolitiikkaa, mutta sittemmin menetelmä on levinnyt myös koulutukseen ja useille eri sosiaalialan sektoreille. Menetelmälle on ominaista yli- kansallisen toimijan vaikutusvalta kansallisvaltioiden yläpuolella ja sitä kautta kansallisten politiikkojen koordinointi erilaisten suositusten ja vertaisanalyysien (benchmarkings) kautta. Symposiumissa aiheesta käyty keskustelu voidaan kiteyttää kahteen keskeiseen kysymykseen:

- Onko avoimen koordinoinnin menetelmästä muodostumassa yksi ylikansallisen hallinnan keskeinen muoto myös koulutussektorilla?

- Kuinka avoimen koordinoinnin menetelmä eroaa muiden järjestöjen, kuten OECD:n hallintamuodoista?

Avoimen koordinoinnin menetelmä on iältään vielä suhteellisen nuori, joten perusteellisen kokonaiskuvan luominen sen vaikutuksista koulutussektorin eri tasoilla on toistaiseksi vaikeaa. Professori Roger Dalen mukaan OMC on olennainen osa hallinnan muotoa erityisesti niillä sektoreilla, joilla EU on toistaiseksi pystynyt harjoittamaan vain rajattua lainsäädäntövaltaa. Näihin sektoreihin lukeutuu selkeästi myös koulutus, jossa järjestö on enimmäkseen tähän asti harjoittanut suosituksiin, politiikkalinjauksiin ja tietotuotantoon perustuvaa nk. pehmeää lainsäädäntöä. Avoimen koordinoinnin menetelmä merkitsee askelta ylikansallisen hallinnon suuntaan, jolloin EU:n taholta asetetut tavoitteet, säännökset ja normit ohjaavat aiempaa suoremmin kansallisvaltioiden koulutuspolitiikkaa.

Dalen mukaan avoimen koordinoinnin menetelmä eroaa OECD:n harjoittamista hallintamuodoista erityisesti siinä, että se on sisällöltään laajempi ja monitahoisempi kuin ns. agenda-setting (politiikkasuositusten pohjalta esitettyjen uudistusehdotusten tuominen jäsenvaltioiden kansallisille esityslistoille). Toisaalta OECD:nkin toiminnassa on 2000-luvulla ollut havaittavissa siirtymistä kohti avoimen koordinoinnin tyyppistä menettelytapaa muun muassa teematutkintojen ja indikaattorijulkaisujen kautta. Vertaispainetta on lisännyt OECD:n tutkimustulosten julkinen käsittely joukkotiedotusvälineissä, mihin liittyen symposiumissa esitettiin useita puheenvuoroja. Esimerkkejä kuultiin mm. PISA-tutkimuksen vaikutuksista Saksassa ja Tanskassa. Puheenvuoroissa todettiin vertailujen hyödyllisyys, mutta korostettiin paradoksia, jossa OECD:n tutkimukset ovat saavuttaneet sekä kansainvälisissä että kansallisissa tiedotusvälineissä keskeisen aseman analyyttiseksi luonnehditun "neutraalin” tiedon lähteenä, vaikka kulttuurin ja koulutuksen 
kentillä arvolatauksetonta tutkimusta ei voi todellisesti olla olemassa.

\section{GATS-SOPIMUS JA}

\section{KOULUTUSPOLITIIKKA}

$\perp$

loinen symposiumissa esille noussut merkittävä asiakokonaisuus liittyi GATS-sopimukseen (General Agreement on Trade in Services) ja sen vaikutuksiin kansallisessa koulutuspolitiikassa. GATS on Maailman kauppajärjestö WTO:n jäsenmaiden Uruguayn kierroksen yhteydessä 1994 solmima sopimus, jonka tavoitteena on poistaa kansainvälisen kaupan esteet palveluteollisuudelta.

Sopimus on aiheuttanut runsaasti keskustelua erityisesti julkisten palvelujen (mm. terveydenhuolto, koulutus, posti- ja telepalvelut sekä julkinen liikenne) suhteen. Symposiumissa alustanut professori Susan Robertson totesi, että yksi sopimuksen kiistanalaisimmista osa-alueista on juuri koulutus, joka on perinteisesti kuulunut kansallisten hallitusten päätösvallan piiriin. Koulutus ja muut julkiset palvelut on nähty välttämättöminä demokraattiselle ja avoimelle päätöksenteolle sekä sosiaaliselle vakaudelle. Euroopan unioni neuvottelee GATS-sopimuksesta jäsenmaidensa antamalla mandaatilla. Suomi on Ruotsin ohella ainoa EU-maa, joka ei ole vielä tehnyt sitoumuksia markkinoille pääsystä tai kansallisesta kohtelusta koulutuspalvelujen alalla, vaikka asiaa koskevia pyyntöjä on Suomelle esitetty.

GATS-sopimuksen laajemmasta sitomisesta koulutukseen ovat kiinnostuneet erityisesti ne osapuolet, jotka hyötyvät sopimuksesta eniten, ts. suuret koulutuspalveluja tuottavat maat kuten Yhdysvallat. Koulutuksesta on muodostumassa yksi merkittävimmistä vientituotteista, jonka arvo OECD:n alueella oli vuosituhannen taitteessa noin 30 miljardia US dollaria ja jonka vienti on yksi nopeimmin kasvavista aloista. Esimerkiksi Australialle koulutus on tärkeämpi vientiartikkeli kuin Suomessa ainakin yhtä hyvin tunnettu viini. Robertsonin mukaan sopimuksen heikoimmaksi osapuoleksi jää kehittyvä maailma (kehitysmaat). Erityisesti palveluja tuovissa maissa (importing countries) sopimus voi aiheuttaa täysin uudenlaisen riippuvuussuhteen palveluja tuottaviin maihin ja vaarantaa maiden tasapainoisen demokratiakehityksen.

Vertailevan aikuiskoulutustutkimuksen kentällä erityisen kiintoisia olivat proferssori Kenneth Wainin ja professori Andy Greenin alustukset. Wain käsitteli oppivaa yhteiskuntaa jälkimodernissa maailmassa ja perusti esityksensä tuoreeseen kirjaansa Learning Society in the Postmodern World. Hän analysoi ja korosti esityksessään, miten aikuiskoulutuksen ja elinikäisen oppimisen merkitys ja poliittinen agenda ovat historian kulussa muuttuneet merkittävästi saavuttaessa laajentuvan Euroopan unionin aikakauteen. Samalla hän tähdensi, ettei muutos kosketa vain elinikäistä oppimista sinänsä vaan myös koulutuksen asemaa ja merkitystä, sekä laajemmin, koulutuspoliittisen ja filosofisen ajattelun murrosta jälkimodernissa maailmassa.

Green tarkasteli esityksessään paikallisia eroja Euroopan elinikäisen oppimisen järjestelmissä. Hän mallitti eurooppalaisia aikuiskoulutusjärjestelmiä monipuolisen ja kattavan empiirisen aineiston pohjalta. Aikuiskoulutuksen alueellisen eroavuuden analyysiin hän kytki useita sosiaalisia ja taloudellisia indikaattoreita, kuten tuottavuuden, tulonjaon, rikollisuuden, luottamuksen ja kansalaistoiminnan alueelliset indikaattorit. Vakuuttavan analyysinsä perustalta Green päätyi siihen, ettei Euroopassa ylikansallisten järjestöjen yhtenäistävistä toimenpiteistä huolimatta voida puhua yhdestä eurooppalaisesta elinikäisen oppimisen mallista, vaan alueiden sosiaalisten, kulttuuristen ja historiallisten tekijöiden erottelemista malleista. Näistä yksi selkeästi erottuva malli on Greenin mukaan edelleen pohjoismaisen hyvinvointivaltiomallin perustalle rakentuva elinikäisen oppimisen malli.

Symposiumissa kuultujen alustusten perusteella voidaan todeta, että ylikansallisten järjestöjen ja niiden jäsenmaiden väliset suhteet vaihtelevat luonteeltaan merkittävästi. Ylikansallisten järjestöjen asettamat koulutuspoliittiset tavoitteet (EU) ja koulutuksen läpinäkyvyyttä lisäävät vertais- ja indikaattoritutkimukset (OECD) asettavat kansalliselle koulutuspoliittiselle päätöksenteolle uudenlaisia kasvavia haasteita. Symposium antoi osallistujille mahdollisuuden vaihtaa ajatuksia ja syventää käsityksiä koulutuksen globaalista tilasta ja vuosituhannen alun koulutuspoliittisesta murroksesta. Tällainen mahdollisuus sai runsaasti kiitosta niin yleisön kuin alustajienkin taholta.

Johanna Kallo, Risto Rinne ja

Sanna Hokka 